\title{
Retail IT and customer loyalty: The moderating role of customer age
}

Received (in revised form): 30 th June 2010

\section{Irene Gil-Saura}

has been a professor in the Marketing Department of the University of Valencia since 1988, and has been a visiting scholar at several European universities. Her studies have been published in several international journals. She is currently interested in service marketing, consumer behaviour and retailing.

\section{Maria-Eugenia Ruiz-Molina}

is an assistant professor in the Marketing Department at the University of Valencia, where she earned her PhD in Business Administration and Management. Her current research interests are consumer behaviour and retailing.

\section{Haydée Calderón-García}

is an associate professor in the Marketing Department of the University of Valencia. Her studies have been published in several international journals. Her current research interest is international marketing.

ABSTRACT Information technology (IT) may represent a source of competitive advantage for retailers. Notwithstanding, there is debate in the literature about the way in which IT influences supplier-customer relationships. In addition, the conclusions regarding the influence of consumer age on attitudes towards the retailer's IT solutions have been mixed. This article proposes and tests a model for the influence of the retailer IT on customer loyalty towards the retailer, evaluating the role of consumer age as a moderator of this relationship. Our results provide evidence of the existence of a two-way positive influence of IT solutions on customer loyalty towards the retail store, that is, through attitude and commitment.

Journal of Retail \& Leisure Property (2010) 9, 357-371.

doi:10.1057/rlp.2010.13

Keywords: information technology; attitude; commitment; loyalty; consumer age; retailing

\section{INTRODUCTION}

Maintaining a portfolio of loyal clients involves increasing difficulties in the present context in which many economic sectors are moving from

Correspondence:

Maria-Eugenia Ruiz-Molina Marketing Department, University of Valencia, Avda. Naranjos, s/n, Valencia 46022, Spain personal communications with the customer to phone or online customer service. Whereas the information and communication technologies (IT) have allowed the fast growth of the service industry through enhanced safety, convenience, accurateness, flexibility, variety and reliability of internal business processes (Lapierre, 2000), improving the total 
efficiency of the supply chain through higher levels of commitment and a long-term orientation (Kent and Mentzer, 2003), there are segments of consumers who consider the service supplier's technology as a source of dissatisfaction (Mick and Fournier, 1998; Parasuraman and Colby, 2001; Burke, 2002; Walker et al, 2002; Snellman and Vihtkari, 2003). In this sense, companies need to consider the determinants of customer loyalty and their relative importance in order to affect service delivery (Lewis and Soureli, 2006). Among the determinants of customer loyalty towards the store, the literature points out customer attitudes and store commitment (Bloemer and de Ruyter, 1998).

Both attitudes and commitment may be positively influenced by the IT solutions implemented by the retailer. From the customer's point of view, information and communication technologies allow improvements in retailer service (Ellram et al, 1999; Lowson, 2001), saving shopping time through a wider assortment and one-stop shopping (Messinger and Narasimhan, 1997). As attitude formation is influenced by previous experiences, these benefits derived from the retailer's IT solutions might have a positive influence on customer attitude towards the store. In addition, literature has reported the positive influence that provider's investment in IT exerts on customer commitment (Kent and Mentzer, 2003). In particular, buyers feel more optimistic towards the future of the relationship with their providers when they perceive that they make an effort to maintain the relationship, with investments effected by providers generating trust in buyers over the extent of the seller's commitment to the relationship (Sharland, 1997; Kent and Mentzer, 2003).

Notwithstanding, mature adults were raised in a different era than younger people and thus are more comfortable with a lifestyle and level of technology particular to their generation (Goodwin and McElwee, 1999). In this regard, customer age may exert a moderating role in the relationship between use of IT solutions by the retailer and customer loyalty.

In this context, focusing on retailing, the present article aims to achieve a double aim. Our first objective is to test the influence of the retailer's technology on customer attitude and commitment, and subsequently on customer loyalty towards the retailer. As a second objective, we aim to analyse the role of customer age on the assessment of the retailer's technology, as well as on the relationships between this construct and the rest of variables, that is, customer attitude, commitment and loyalty.

\section{LITERATURE REVIEW}

\section{Information technology}

IT refers to 'all forms of technology utilized to create, capture, manipulate, communicate, exchange, present, and use information in its various forms (business data, voice conversations, still images, motion pictures, multimedia presentations' and so on (Ryssel et al, 2004, p. 198). Two main dimensions have been considered for IT assessment, that is, IT advancement and IT alignment (Hausman and Stock, 2003; Wu et al, 2006). The former has been defined as the extent to which a firm adopts 
the most sophisticated technology as a measure of the proactivity of the company in the adoption and implementation of the IT to offer solutions to its customers ahead of competitors (Wu et al, 2006). The latter, that is, IT alignment, is defined as the extent to which a firm's IT is compatible with that of its channel partners, among them their customers (Powell, 1992).

Although technology might improve customer relationship management and service customization, IT can be source of satisfaction or dissatisfaction depending on customer attitude towards technology (Joseph et al, 1999; Parasuraman and Colby, 2001; Walker et al, 2002) and/or employee responsiveness (Meuter et al, 2000; Bitner, 2001). In addition, Mick and Fournier (1998) pointed out the fact that, although IT integrates people who are further apart, it might increase isolation between people in close proximity, involving experiences of efficacy and ineptitude. In particular, Snellman and Vihtkari (2003) obtain approximately the same number of complaints about an unsatisfactory service in traditional bank as in technology-based banking services. This fact is explained on the basis of rude or uncaring employee behaviour in traditional banking services and failures related to errors in service design in technology-based banking.

\section{Customer attitude and commitment}

Attitude refers to a learnt predisposition to respond consistently favourably or unfavourably to an object. In the business context, attitude is identified with attachment to the firm (Bove and Johnson, 2000). As attitudes are learnt, they are affected by information and experiences (Wilkie, 1994). In particular, attitude formation is based on three types of processes: descriptive, informational and inferential perception formation (Fishbein and Ajzen, 1975). Descriptive perceptions or beliefs result from direct observation of the store services or by drawing on previous experience with the store. Perceptions are also formed by accepting information about evaluative criteria provided by an outside source. Inferential perceptions are constructed by the consumer based on descriptive or informational perceptions.

In addition, the fact that attitudes are predispositions to respond leads to its relationship with actual consumer behaviour. According to the Theory of Reasoned Action (Ajzen and Fishbein, 1980), consumer attitude influences consumer purchase behaviour. According to this theory, behaviour is determined by intentions, which are also influenced by attitudes and subjective norms. The relationship between attitude and behavioural intentions has been widely examined and supported empirically (Kim and Hunter, 1993; Berger et al, 1994).

With regard to commitment, it has been defined as the degree to which the consumer wishes to build and maintain a continuous relationship with a company in the long run (Morgan and Hunt, 1994). In particular, store commitment has been defined as the binding of an individual to his/her store choice (Bloemer and de Ruyter, 1998). As a result of decision making, as well as evaluative processes, a consumer becomes committed to the store, and therefore becomes store loyal. 


\section{Customer loyalty}

Dick and Basu (1994) define loyalty as the conjunction of a positive attitude and repeat patronage. Loyalty in the service sector is perhaps more difficult to conceptualize than in the scope of products because of the characteristics of services (Bloemer et al, 1998; Mittal and Lassar, 1998). In this sense, intangibility and lack of standardization might involve that reliability and trust play a more important role in building and maintaining loyalty (Dick and Basu, 1994). Furthermore, the inseparability of production and consumption and the customer participation in service delivery reflect the interpersonal component of services and add an emotional dimension to loyalty (Javalgi and Moberg, 1997). In this context, customer loyalty depends to a great extent on service customization (Ball et al, 2006), personal communication management (Jones and Farquhar, 2003) and feelings of enjoyment with regard to shopping at the store (Wong, 2004).

In the case of store loyalty, it has been defined as the biased behavioural response, expressed over time, by a consumer with respect to one store out of a set of stores, which is a function of both decision making and evaluative processes, resulting in brand commitment (Bloemer and de Ruyter, 1998). The critical part of this definition is store commitment, as in case of absence of store commitment a patron to a store is merely spuriously loyal, that is, repeat visiting behaviour is directed by inertia (Dick and Basu, 1994). In this sense, Srinivasan et al (2002) define loyalty as a customer's favourable attitude towards the retailer that results in repeat buying behaviour.

\section{Consumer age and retail IT}

As older consumers would perceive the retailer's IT solutions to be too complex to use (Dean, 2008), it might be assumed that younger consumers may appreciate to a greater extent the retail technology. Nevertheless, research conducted on the influence of consumer age on attitudes towards retailer's IT solutions is inconclusive.

On the one hand, several studies on grocery store shoppers (Dabholkar et al, 2003; Phang et al, 2006; Weijters et al, 2007) conclude that age has no main effect or moderating influence on attitudes towards retail IT solutions, such as self-scanning checkout and online services. In this regard, after performing a cluster analysis of retail customers' attitudes towards, and use of, self-service technologies (SST), Dean (2008) states that age is a simplistic label that does not necessarily describe an individual's attitudes or behaviour, as both young and elderly consumers are significant in the cluster most accepting SST and in the cluster most resistant to SST. Moreover, Niemelä-Nyrhinen (2007) points out that Finnish consumers aged between 50 and 60 years, in contrast to the stereotypes, have low levels of technology anxiety and high levels of experience of Internet usage.

On the other hand, some studies point out that the older a customer is, the less positive he is likely to be about obtaining customer service over a technology-based medium (Burke, 2002; Dulude, 2002). In particular, Simon and Usunier (2007) observe that age has a strong negative effect on preference for SST over employee contact. 


\section{PROPOSED MODEL AND HYPOTHESES}

Following the previous literature review, we expect customer assessment on retailer's IT solutions to act as an antecedent of customer attitude and commitment, and these two variables in turn are expected to have a positive influence on customer loyalty towards the retailer. These relationships between constructs are shown in Figure 1.

First, as attitudes may be affected by previous experiences with the store and the IT solutions of the retailer facilitate customer purchases, we expect to find a positive relationship between customer assessment of the retailer's IT and customer attitude towards the store. Therefore, we posit the following hypothesis:

Hypothesis 1: The better the assessment of the retailer's IT solutions, the more positive the customer attitude towards the retailer.

In addition, considering the empirical evidence that supports the positive influence of investment in IT on customer commitment in the context of business-to-business relationships (Rebolledo et al, 2005), we assume that, similarly, retailer technology will act as an antecedent of customer commitment in a business-to-customer setting. Thus, we enunciate the second hypothesis as follows:

Hypothesis 2: The better the assessment of the retailer's IT solutions, the higher the level of customer commitment towards the retailer.

Among the factors that exert a fundamental influence in customer loyalty, the role of customer attitude has been emphasized (Dick and Basu, 1994). In particular, loyalty towards the store has been defined as the biased behavioural response expressed over time by some decision-making unit with respect to one or more alternative brands out of a set of such brands. Loyalty is a consequence of psychological decision making and evaluative processes that result in the commitment with a store (Knox and Walker, 2001). Thus, there is empirical evidence of the positive relationship between attitude and loyalty in retailing (Macintosh and Lockshin, 1997).

Hypothesis 3: The more positive the customer attitude, the higher the levels of customer loyalty towards the retailer.

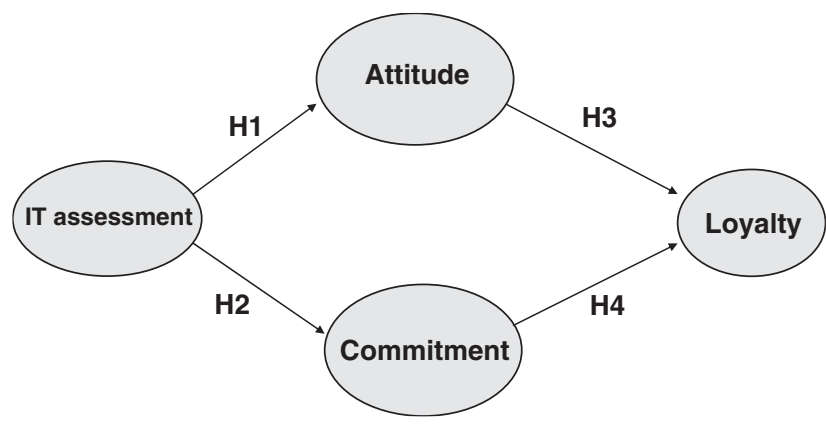

Figure I: Proposed model. 
Similarly, commitment has been pointed out as one of the main factors that determine the development and maintenance of a relationship that contributes to create value between customer and supplier (Morgan and Hunt, 1994); also of relevance is the positive and direct influence of value on customer loyalty towards the supplier (Garbarino and Johnson, 1999; Fullerton, 2005; Evanschitzky et al, 2006; Shabbir et al, 2007). In particular, Bloemer and de Ruyter (1998) consider that store commitment is a necessary condition for store loyalty to occur. Thus, we enunciate the fourth hypothesis as follows:

Hypothesis 4: The higher the level of customer commitment, the higher the levels of customer loyalty towards the retailer.

Finally, according to Simon and Usunier (2007), we understand that older customer may be more reluctant to make use of the retailer's IT solutions than younger patrons. In this regard, we expect to find significant differences in customer assessment of retailer's technology across age groups. In addition, we expect customer age to exert a moderating role on the hypothesized relationships of our proposed model. Therefore, we state the following hypothesis:

Hypothesis 5: Younger customers assess the retailer's IT solutions more positively than older customers.

Hypothesis 6: Customer assessment in IT has a greater influence on attitude, commitment and loyalty for younger consumers in comparison to older consumers.

In particular:

Hypothesis 6a: Customer assessment in IT has a greater influence on attitude for younger consumers in comparison to older consumers.

Hypothesis 6b: Customer assessment in IT has a greater influence on customer commitment towards the retailer for younger consumers in comparison to older consumers.

Hypothesis 6c: Customer attitude towards the retailer has a greater influence on customer loyalty for younger consumers in comparison to older consumers.

Hypothesis 6d: Customer commitment towards the retailer has a greater influence on customer loyalty for younger consumers in comparison to older consumers.

\section{METHODOLOGY}

In order to achieve our aim, we perform a quantitative analysis through a personal survey to consumers. Table 1 exhibits the main characteristics of the research. 
Table I: Technical details of the research

\begin{tabular}{ll}
\hline Universe & $\begin{array}{l}\text { Customers of retail stores selling } \\
\text { - Grocery }\end{array}$ \\
& Clething/footwear \\
& Electronics/electrical appliances \\
Geographical scope & Spain \\
Sample size & 400 consumers (I00 for each activity) of 51 stores \\
Sample design & Personal survey at the exit of the store \\
Data collection period & September-October 2007 \\
Statistical techniques & Descriptive analysis \\
& $\begin{array}{l}\text { Analysis of variance (ANOVA) } \\
\text { Confirmatory factor analysis (CFA) } \\
\text { Structural equations model }\end{array}$ \\
Statistical software & SPSS version I5.0 \\
& EQS 6.I
\end{tabular}

The stores for conducting surveys were selected among the main companies in each activity sector (following their NACE - National Classification of Economic Activities - and TEA - Tax on Economic Activities - codes obtained from SABI (Iberian Accounting Analysis System), an Informa database that contains the annual reports of the most important Spanish and Portuguese companies) in terms of total sum of the assets in the company's balance sheet.

With regard to the consumers sample, respondents were randomly selected and interviewed at the store exit. A probability-sampling process has been followed in order to guarantee that the sample is representative of the population in terms of gender and age. Table 2 shows its distribution in terms of its classification variables.

The items included in the questionnaire, regarding customer assessment of IT solutions, have been adapted from the scale proposed by $\mathrm{Wu}$ et al (2006), whereas the valuation of the global attitude of the client is of Bove and Johnson (2000). Commitment has been adapted from Hennig-Thurau (2004). Finally, items for measuring loyalty towards the retailer have been adapted from Srinivasan et al (2002) and Anderson and Srinivasan (2003). In all cases, items were ranked on a 5-point scale.

Once data are collected, a principal component analysis (PCA) is performed in order to group the items into factors. Next, in order to confirm the validity of the proposed conceptual network, a covariance structure analysis or the estimation of a structural equations model is performed following the two-step procedure recommended by Anderson and Gerbing (1988). This procedure involves, first, analysing the quality of the constructs measurements through a confirmatory factor analysis (CFA), and, second, estimating a structural, theoretical or causal model that allows to obtain information about the relations between the constructs that are stated in the hypotheses of this study. In this way, the 
Table 2: General sample information

\begin{tabular}{lrc}
\hline Variables & Number & $\%$ \\
\hline Stores & & \\
Number of stores & & \\
- Grocery & 8 & 15.68 \\
- Clothing/footwear & 16 & 31.37 \\
- Electronics/electrical appliances & 16 & 31.37 \\
- Furniture/decorations & 11 & 21.57 \\
Length of patronage & & \\
- 0-5 years & 242 & 60.5 \\
- 6-10 years & 119 & 29.75 \\
- II-15 years & 19 & 4.75 \\
- More than 15 years & 19 & 4.75 \\
Consumers & & \\
Gender & & \\
- Male & 184 & 46 \\
- Female & 216 & 54 \\
Age & & \\
- 18-25 years & 25 & 28.3 \\
- 26-35 years & 113 & 39 \\
- 36-45 years & 156 & 19.5 \\
- 46-55 years & 78 & 5.5 \\
- 56-65 years & 22 & 1.5 \\
- More than 65 years & 6 & 0.3 \\
Educational level & & 28.8 \\
- Without studies & 11.75 \\
- Primary studies & 115 & 19 \\
- Secondary studies & 207 & \\
- University studies & 76 & \\
\hline
\end{tabular}

hypotheses regarding the causality relations between latent and/or observed variables can be simultaneously tested.

In addition, in order to test the influence of customer age on the perception of the retailer's technology and its consequents, first, an analysis of variance (ANOVA) is conducted regarding the customer assessment of the retailer's IT solutions. Finally, a multi-group or multisample structural equation model is estimated. Through this technique, we aim to test the existence of significant differences in the relationships between IT assessment, attitude, commitment and loyalty towards the retailer across age groups.

\section{ANALYSES AND RESULTS}

First, as a preliminary analysis, in order to identify the structure of the relations between the variables that compose the different scales, a PCA with rotation VARIMAX is performed to obtain the factor structure of the three multi-item variables. The resulting rotated component matrix for each construct is shown in Table 3.

In spite of the distinction between IT advancement and IT alignment highlighted in the literature, the results show the existence of a unique factor that explains 73.06 per cent of the total variance. Similarly, unifactor scales are obtained for customer attitude and loyalty, which explain 64.46 per cent and 53.86 per cent of the total variance, respectively.

Factor analysis has not been performed for commitment, as it is represented by just one item. 
Table 3: Component matrix for multi-item constructs

\begin{tabular}{|c|c|}
\hline $\begin{array}{l}\text { Customer assessment of retailer's IT (KMO: } 0.8 \text { I 0; determinant: } 0.073 \text {; Bartlett's test of } \\
\text { sphericity (sign. level)::0.000. Total variance explained: } 73.06 \%)\end{array}$ & Component I \\
\hline $\begin{array}{l}\text { ITI. This store invests in technology. } \\
\text { IT2. The IT of this store is always the latest. } \\
\text { IT3. In relation to its competitors, the technology of this store is more advanced. } \\
\text { IT4. This store considers my opinion as a customer to coordinate and to develop its IT } \\
\text { in order to improve the service and to better satisfy my needs. }\end{array}$ & $\begin{array}{l}0.922 \\
0.909 \\
0.921 \\
0.630\end{array}$ \\
\hline $\begin{array}{l}\text { Attitude (KMO: } 0.682 \text {; determinant: } 0.549 \text {; Bartlett's test of sphericity (sign. level)::0.000. } \\
\text { Total variance explained: } 64.46 \%)\end{array}$ & \\
\hline $\begin{array}{l}\text { A1. This STORE is good } \\
\text { A2. It would recommend this STORE to others } \\
\text { A3. I consider myself to be a loyal patron of this STORE }\end{array}$ & $\begin{array}{l}0.796 \\
0.802 \\
0.810\end{array}$ \\
\hline $\begin{array}{l}\text { Loyalty (KMO: } 0.836 \text {; determinant: } 0.224 \text {; Bartlett's test of sphericity (sign. level)::0.000. } \\
\text { Total variance explained: } 56.83 \% \text { ) }\end{array}$ & \\
\hline $\begin{array}{l}\text { LI. As long as the present service continues, I doubt that I would switch STORE } \\
\text { L2. I try to use the STORE whenever I need to make a purchase. } \\
\text { L3. When I need to make a purchase, this STORE is my first choice } \\
\text { L4. I like using this STORE } \\
\text { L5. To me this STORE is the best STORE to do business with }\end{array}$ & $\begin{array}{l}0.696 \\
0.692 \\
0.769 \\
0.783 \\
0.821\end{array}$ \\
\hline
\end{tabular}

Solution cannot be rotated, as there is only one factor.

Table 4: Confirmatory factor analysis results

\begin{tabular}{|c|c|c|c|c|c|c|}
\hline Construct & Ítem & St. loading factor (SE) & $t$ & Cronbach's $\alpha$ & $\begin{array}{c}\text { Composite } \\
\text { reliability }\end{array}$ & $\begin{array}{c}\text { Average variance } \\
\text { extracted }\end{array}$ \\
\hline \multirow{4}{*}{$\begin{array}{l}\text { Assessment of } \\
\text { retailer's IT }\end{array}$} & ITI & 0.901 & - & 0.851 & 0.883 & 0.666 \\
\hline & IT2 & $0.883(0.034)$ & 26.722 & - & - & - \\
\hline & IT3 & $0.913(0.031)$ & 30.792 & - & - & - \\
\hline & IT4 & $0.487(0.067)$ & 10.224 & - & - & - \\
\hline \multirow[t]{3}{*}{ Attitude } & Al & 0.633 & - & 0.728 & 0.725 & 0.469 \\
\hline & $\mathrm{A} 2$ & $0.707(0.125)$ & 10.980 & - & - & - \\
\hline & $\mathrm{A} 3$ & $0.711(0.141)$ & 9.373 & - & - & - \\
\hline \multirow[t]{5}{*}{ Loyalty } & LI & 0.601 & - & 0.802 & 0.811 & 0.466 \\
\hline & L2 & $0.594(0.084)$ & 9.286 & - & - & - \\
\hline & L3 & $0.688(0.101)$ & 9.832 & - & - & - \\
\hline & L4 & $0.739(0.100)$ & 9.315 & - & - & - \\
\hline & L5 & $0.771(0.110)$ & 9.176 & - & - & - \\
\hline
\end{tabular}

Chi-square Satorra-Bentler: 64.67; degrees of freedom: 5I; CFI: 0.990; IFI: 0.990; Bentler-Bonett NNFI: 0.987; RMSEA: 0.026 .

After this first exploratory phase, the results of the PCA were submitted to CFA in order to measure their goodness-of-fit. As a result, it is observed that the fit indexes range about 0.9 , which indicates an acceptable model fit (Table 4). Furthermore, the mean square error is small (RMSEA $=0.026)$.

From the results shown in Table 4, the reliability of the scales can also be confirmed, as the composite reliability and the Cronbach's coefficient $\alpha$ for all the constructs are above the recommended value of 0.7 , the extracted variances are higher than 50 per cent or near to this value and the standardized factor loadings are statistically significant for all the items. All this allows us to confirm the convergent validity of the model. 
Table 5: Means, standard deviations and correlations between constructs

\begin{tabular}{lcccccc}
\hline \multirow{2}{*}{ Construct } & Mean & SD & \multicolumn{4}{c}{ Correlations } \\
\cline { 4 - 6 } & & & $F I$ & $F 2$ & $F 3$ & F4 \\
\hline FI. Assessment of retailer's IT & 3.202 & 0.883 & - & - & - & - \\
F2. Attitude & 3.819 & 0.664 & 0.446 & - & - & - \\
F3. Commitment & 3.451 & 0.903 & 0.252 & 0.596 & - & - \\
F4. Loyalty & 3.674 & 0.696 & 0.387 & 0.809 & 0.535 & - \\
\hline
\end{tabular}

On the other hand, the correlations between constructs are calculated in order to test the discriminant validity (Table 5).

Focusing on the highest correlation value, that is, customer attitude and loyalty (0.809), we estimate the confidence interval described by Anderson and Gerbing (1988) to test its discriminant validity. This test requires calculating a confidence interval of \pm 2 standard errors for the correlation between both constructs, and determining whether this interval includes the value 1 . In case this interval does not include the value 1 , the discriminant validity is confirmed.

In this case, the maximum correlation is achieved between attitude and loyalty ( 0.809$)$, being the standard error of the correlation between these factors 0.040 . Thus, the confidence interval is $(0.729 ; 0.889)$, being the discriminant validity therefore confirmed, as the interval does not include the unit.

Once the validity of the model is confirmed, we estimate the structural equation model shown in Figure 1, obtaining the results displayed in Table 6.

All the estimated parameters are statistically significant (Table 6). Thus, the hypothesized relationships are supported by the data of the whole sample of retail customers. The global model fit is acceptable, as the fit indexes are approximately the recommended value of 0.9 and RMSEA is lower than the reference value of 0.08 .

Notwithstanding, according to Hypotheses 5 and 6, we expect to find significant differences in customer assessment of the retailer's IT across age groups, as well as in the relationships between this construct and the rest of constructs in the model (customer attitude, commitment and loyalty). In order to test these hypotheses, first, an ANOVA analysis is performed for three age groups including similar number of observations (Table 7).

Younger retail customers, that is, customers in age groups 1 and 2 (less than 36 years old and between 36 and 45 years), show higher scores for all items of the IT assessment scale. Nevertheless, significant differences at 10 per cent are only found for items IT1 and IT3. Thus, only partial support is obtained for Hypothesis 5.

The next step was to conduct a multi-group analysis. In this way, we aim to test the existence of significant differences in the relationships between constructs across age groups. Results are shown in Table 8 .

The influence of customer assessment of the retailer's IT solutions on customer attitude and commitment does not differ significantly across age groups. Similarly, no significant differences are observed for the relationship between customer attitude and loyalty between younger and 
Table 6: Structural equations model results

\begin{tabular}{lccll}
\hline Relation & $\begin{array}{c}\text { Standardized } \\
\text { parameter }\end{array}$ & $S E$ & $T$ & Hypotheses \\
\hline $\mathrm{IT} \rightarrow$ Attitude & 0.453 & 0.038 & $5.876^{*}$ & Hypothesis I supported \\
$\mathrm{IT} \rightarrow$ Commitment & 0.266 & 0.061 & $4.653^{*}$ & Hypothesis 2 supported \\
Attitude $\rightarrow$ Loyalty & 0.836 & 0.155 & $6.786^{*}$ & Hypothesis 3 supported \\
& 0.203 & 0.033 & $3.586^{*}$ & Hypothesis 4 supported \\
\hline
\end{tabular}

* Significant, $p<0.05$.

Chi-square Satorra-Bentler: I5I.09; degrees of freedom: 6I; CFI: 0.940; IFI: 0.94I; Bentler-Bonett NNFI: 0.923; RMSEA: 0.062 .

Table 7: Customer evaluation of the retailer technology across age groups:Average values and significant differences

\begin{tabular}{|c|c|c|c|c|}
\hline & $\begin{array}{l}\text { Group I: } \\
<36 \text { years } \\
(N=135)\end{array}$ & $\begin{array}{l}\text { Group } 2: \\
\text { 36-45 years } \\
(N=154)\end{array}$ & $\begin{array}{l}\text { Group } 3 \text { : } \\
>45 \text { years } \\
(N=103)\end{array}$ & $\begin{array}{c}\text { Differences } \\
\text { between groups }{ }^{\mathrm{a}}\end{array}$ \\
\hline ITI. This STORE invests in technology & 3.53 & 3.48 & 3.29 & $1-3$ \\
\hline $\begin{array}{l}\text { IT2. This STORE has the most advanced } \\
\text { technology }\end{array}$ & 3.39 & 3.40 & 3.20 & - \\
\hline $\begin{array}{l}\text { IT3. In comparison to its competitors, } \\
\text { the technology of this STORE is } \\
\text { more advanced }\end{array}$ & 3.34 & 3.34 & 3.13 & $1-3,2-3$ \\
\hline $\begin{array}{l}\text { IT4. This STORE considers my opinion } \\
\text { as a customer on decisions involving } \\
\text { IT coordination and development } \\
\text { in order to improve services and to } \\
\text { better satisfy my needs as a client }\end{array}$ & 2.73 & 2.80 & 2.60 & - \\
\hline
\end{tabular}

${ }^{a}$ The Tukey post hoc multiple comparison test was used to test for the significance of differences between types of retailers. Only the statistically significant differences between groups at the $10 \%$ level are shown.

older customers. Notwithstanding, Hypothesis $6 \mathrm{~d}$ is partially supported in the sense that the youngest customers show a lower intensity in the relationship Commitment $\rightarrow$ Loyalty than retail customers aged between 36 and 45 years. In contrast, the latter show a significantly stronger link between commitment and loyalty than the oldest retail customers, that is, those who are older than 45 years. This evidence may be explained by the fact that both the youngest and the oldest groups - that may include many students, part-time workers and pensioners without family obligations have more time to obtain information about the services offered by different retailers and to visit and compare different stores, and thus are more sensitive than middle-age groups to some store actions, such as promotions, when deciding to visit the store.

\section{CONCLUSIONS}

The literature recognizes the need to explore the determinants of store loyalty and their relative importance in order to affect service delivery (Lewis and Soureli, 2006). In this sense, the present article provides evidence about the positive influence of customer attitudes and store commitment on store loyalty. In turn, both customer attitudes and commitment are determined by the level of advancement and alignment of the retailer's IT. In other words, our results support the importance for the retailer of investing in IT solutions, as they have a two-way positive 
Table 8: Results of multi-group analysis

\begin{tabular}{|c|c|c|c|c|c|c|}
\hline & \multicolumn{3}{|c|}{ Non-standard coefficients } & \multirow{2}{*}{$\begin{array}{c}X 2 \text { diff. between } \\
\text { groups } 1-2 \text { and } \\
1-3\end{array}$} & \multirow[t]{2}{*}{$p$-value } & \multirow[t]{2}{*}{ Hypotheses } \\
\hline & $\begin{array}{l}\text { Group I: } \\
<36 \text { years } \\
(N=135)\end{array}$ & $\begin{array}{c}\text { Group 2: } \\
36-45 \text { years } \\
(N=154)\end{array}$ & $\begin{array}{l}\text { Group } 3: \\
>45 \text { years } \\
(N=103)\end{array}$ & & & \\
\hline IT $\rightarrow$ Attitude & 0.242 & 0.182 & 0.254 & $\begin{array}{l}0.215 \\
0.571\end{array}$ & $\begin{array}{l}0.643 \\
0.450\end{array}$ & $\begin{array}{l}\text { Hypothesis } \\
\text { 6a not } \\
\text { supported }\end{array}$ \\
\hline IT $\rightarrow$ Commitment & 0.296 & 0.238 & 0.302 & $\begin{array}{l}0.018 \\
0.203\end{array}$ & $\begin{array}{l}0.894 \\
0.653\end{array}$ & $\begin{array}{l}\text { Hypothesis } \\
6 \mathrm{~b} \text { not } \\
\text { supported }\end{array}$ \\
\hline Attitude $\rightarrow$ Loyalty & 0.831 & 1.186 & 1.066 & $\begin{array}{l}0.706 \\
0.047\end{array}$ & $\begin{array}{l}0.401 \\
0.829\end{array}$ & $\begin{array}{l}\text { Hypothesis } \\
6 \mathrm{c} \mathrm{not} \\
\text { supported }\end{array}$ \\
\hline Commitment $\rightarrow$ Loyalty & 0.097 & 0.362 & 0.004 & $\begin{array}{l}5.745 \\
2.969\end{array}$ & $\begin{array}{l}0.017 \\
0.085\end{array}$ & $\begin{array}{c}\text { Hypothesis } 6 d \\
\text { supported }\end{array}$ \\
\hline
\end{tabular}

influence on customer loyalty towards the retail store, that is, both an attitude and a commitment-mediated influence.

Notwithstanding, the effect mediated through customer attitude is stronger than the one operated through customer commitment. In this regard, we understand that retailers should concentrate their efforts on investing in those technologies that contribute to a greater extent to improving the customer experience in the store, as well as the store image.

In addition, customer age does not seem to exert a significant moderating role on the relationships between customer IT assessment and their consequents, that is, attitude and store commitment. This evidence is consistent with some previous studies (Dabholkar et al, 2003; Phang et al, 2006; Weijters et al, 2007; Dean, 2008).

In contrast, there is a significantly weaker link between store commitment and loyalty for customers younger than 36 years and for customers older than 45 years, in comparison to the group of consumers aged between 36 and 45 years. These differences may respond to different motivations. While in the case of younger customers varietyseeking behaviours may be behind the decision to visit another establishment in spite of feeling committed to the store, for older customers competitors' promotional actions may be interfering in the store choice. Further research should be conducted in order to determine the underlying motivations for these differences across age groups. Evidence in this direction is highly important for practitioners, as consumers whose patronage is not based on store loyalty may be lured away by competitors through, for instance, pricing strategies (Bloemer and de Ruyter, 1998). 
Notwithstanding, we understand that this research is not free of limitations. First, a bigger sample size, including more respondents for each age group, might allow us to refine results. In this sense, a sample of more diverse age groups might have yielded additional conclusions.

Furthermore, the following step in this research line should consider an extended model introducing additional variables such as consumer value and its antecedents - that is, relational benefits, sacrifices and switching costs - as well as trust and customer satisfaction, as they have also been appointed in the literature as main determinants of customer loyalty.

Finally, concerning the variable referred to customer assessment of retailer's IT, the question arises on how customers who never or rarely use a store IT systems evaluate the retailer's technology. In this regard, differences between segments across age groups should be examined in greater depth in order to identify the peculiarities of these segments in terms of their main determinants of store loyalty.

\section{ACKNOWLEDGEMENTS}

This research has been financed by the Spanish Ministry of Education and Science (Projects ref.: SEJ2007-66054/ECON).

\section{REFERENCES}

Ajzen, I. and Fishbein, M. (1980) Understanding Attitudes and Predicting Social Behavior. Englewood Cliffs, NJ: Prentice-Hall.

Anderson, J.C. and Gerbing, D.W. (1988) Structural equation modelling in practice: A review and recommended two-step approach. Psychological Bulletin 103: 411-423.

Anderson, R.E. and Srinivasan, S.S. (2003) E-satisfaction and e-loyalty: A contingency framework Psychology \& Marketing 20(2): 123-138.

Ball, D., Coelho, P.S. and Vilares, M.J. (2006) Service personalization and loyalty. Journal of Services Marketing 20(6): 391-403.

Berger, I.E., Ratchford, B.T. and Haines, G.H. (1994) Subjective product knowledge as a moderator of the relationship between attitudes and purchase intentions for a durable product. Journal of Economic Psychology 15(2): 301-314.

Bitner, M.J. (2001) Service and technology: Opportunities and paradoxes. Managing Service Quality 11(6): 375-379.

Bloemer, J. and de Ruyter, K. (1998) On the relationship between store image, store satisfaction and store loyalty. European Journal of Marketing 32(5/6): 499-513.

Bloemer, J., de Ruyter, K. and Peeters, P. (1998) Investigating drivers of bank loyalty: The complex relationship between image, service quality and satisfaction. International Journal of Bank Marketing 16(7): 276-286.

Bove, L.L. and Johnson, L.W. (2000) A customer-service worker relationship model. International Journal of Service Industry Management 11(5): 491-511.

Burke, R.R. (2002) Technology and the customer interface: What consumers want in the physical and virtual store. Journal of the Academy of Marketing Science 30(4): 411-432.

Dabholkar, P.A., Bobbit, L.M. and Lee, E. (2003) Understanding consumer motivation and behavior related to self-scanning in retailing. International Journal of Service Industry Management 14(1): 59-95.

Dean, D.H. (2008) Shopper age and the use of self-service technologies. Managing Service Quality 18(3): 225-238

Dick, A.S. and Basu, K. (1994) Customer loyalty: Toward an integrated conceptual framework Journal of the Academy of Marketing Science 22(2): 99-113.

Dulude, L. (2002) Automated telephone answering systems and aging. Behaviour \& Information Technology 21(3): 171-184.

Ellram, L.M., La Londe, B.J. and Weber, M.M. (1999) Retail logistics. International Journal of Physical Distribution \& Logistics Management 29(7/8): 477-494.

Evanschitzky, H., Iyer, G.R., Plassmann, H., Niessing, J. and Meffert, H. (2006) The relative strength of affective commitment in securing loyalty in service relationships. Journal of Business Research 59(12): 1207-1213. 
Fishbein, M. and Ajzen, I. (1975) Belief, Attitude, Intention, and Behavior: An Introduction to Theory and Research. Reading, MA: Addison-Wesley.

Fullerton, G. (2005) The service quality - Loyalty relationship in retail services: Does commitment matter? Journal of Retailing and Consumer Services 12: 99-111.

Garbarino, E. and Johnson, M.S. (1999) The different roles of satisfaction, trust, and commitment in customer relationships. Journal of Marketing 63: 70-87.

Goodwin, D.R. and McElwee, R.E. (1999) Grocery shopping and an ageing population. International Review of Retail, Distribution and Consumer Research 9(4): 403-409.

Hausman, A. and Stock, J.R. (2003) Adoption and implementation of technological innovations within long-term relationships. Journal of Business Research 56: 681-686.

Hennig-Thurau, T. (2004) Customer orientation of service employees: Its impact on customer satisfaction, commitment and retention. International Journal of Service Industry Management 15(5): 460-478.

Javalgi, R. and Moberg, C. (1997) Service loyalty: Implications for service providers. Journal of Services Marketing 11(3): 165-179.

Jones, H. and Farquhar, J.D. (2003) Contact management and customer loyalty. Journal of Financial Services Marketing 8(1): 71-78.

Joseph, M., McClure, C. and Joseph, B. (1999) Service quality in banking sector: The impact of technology on service delivery. International Journal of Bank Marketing 17(4): 182-193.

Kent, J.L. and Mentzer, J.T. (2003) The effect of investment in interorganizational information technology. Journal of Business Logistics 24(2): 155-175.

Kim, M.S. and Hunter, J.E. (1993) Relationships among attitudes, behavioural intentions, and behavior: A meta-analysis of past research, Part 2. Communication Research 20(3): 331-364.

Knox, S.D. and Walker, D. (2001) Measuring and managing brand loyalty. Journal of Strategic Marketing 9: 111-128.

Lapierre, J. (2000) Customer-perceived value in industrial contexts. Journal of Business \& Industrial Marketing 15(2/3): 122-140.

Lewis, B.R. and Soureli, M. (2006) The antecedents of consumer loyalty in retail banking. Journal of Consumer Behaviour 5(1): 15-31.

Lowson, R.H. (2001) Retail operational strategies in complex supply chains. International Journal of Logistics Management 12(1): 97-111.

Macintosh, G. and Lockshin, L.S. (1997) Retail relationships and store loyalty: A multi-level perspective. International Journal of Research in Marketing 14: 487-497.

Messinger, P.R. and Narasimhan, C. (1997) A model of retail formats based on consumers' economizing on shopping time. Marketing Science 16(1): 1-23.

Meuter, M.L., Ostrom, A.L., Roundtree, R.I. and Bitner, M.J. (2000) Self-service technologies: Understanding customer satisfaction with technology-based service encounters. Journal of Marketing 64(3): 50-64.

Mick, D.G. and Fournier, S. (1998) Paradoxes of technology: Consumer cognisance, emotions and coping strategies. Journal of Consumer Research 25: 123-143.

Mittal, B. and Lassar, W. (1998) Why do customers switch?: The dynamics of satisfaction versus loyalty. Journal of Services Marketing 12(3): 177-194.

Morgan, R.M. and Hunt, S.D. (1994) The commitment-trust theory of relationship marketing. Journal of Marketing 58(3): 20-38.

Niemelä-Nyrhinen, J. (2007) Baby boom consumers and technology: Shooting down stereotypes. Journal of Consumer Marketing 24(5): 305-312.

Parasuraman, A. and Colby, C.L. (2001) Techno-ready Marketing: How and Why Your Customers Adopt Technology. New York: Free Press.

Phang, C., Sutanto, J., Kankanhalli, A., Li, Y., Tan, B. and Teo, H. (2006) Senior citizens' acceptance of information systems: A study in the context of e-government services. IEEE Transactions on Engineering Management 53(4): 555-569.

Powell, T.C. (1992) Organizational alignment as competitive advantage. Strategic Management Journal 13(2): 119-134.

Rebolledo, C., Ricard, L. and Prefontaine, L. (2005) The potential of information technology in facilitating relationship marketing: The case of large Canadian firms. Journal of Relationship Marketing 4(1/2): 57-72.

Ryssel, R., Ritter, T. and Gemunden, H.G. (2004) The impact of information technology deployment on trust, commitment and value creation in business relationships. Journal of Business \& Industrial Marketing 19(3): 197-207.

Shabbir, H., Palihawadana, D. and Thwaites, D. (2007) Determining the antecedents and consequences of donor-perceived relationship quality - A dimensional qualitative research approach. Psychology \& Marketing 24(3): 271-293.

Sharland, A. (1997) Sourcing strategy: The impact of costs on relationship outcomes. International Journal of Physical Distribution \& Logistics Management 27(7): 395-409. 
Simon, F. and Usunier, J. (2007) Cognitive, demographic, and situational determinants of service customer preference for personnel-in-contact over self-service technology. International Journal of Research in Marketing 24(2): 163-173.

Snellman, K. and Vihtkari, T. (2003) Customer complaining behaviour in technology-based service encounters. International Journal of Service Industry Management 14(2): 217-231.

Srinivasan, S.S., Anderson, R. and Ponnavolu, K. (2002) Customer loyalty in e-commerce: An exploration of its antecedents and consequences. Journal of Retailing 78(1): 41-50.

Walker, R.H., Craig-Lees, M., Hecker, R. and Francis, H. (2002) Technology-enabled service delivery. An investigation of reasons affecting customer adoption and rejection. International Journal of Service Industry Management 13(1): 91-106.

Weijters, B., Rangarajan, D., Falk, T. and Schillewaert, N. (2007) Determinants and outcomes of customers' use of self-service technology in a retail setting. Journal of Service Research 10(1): 3-21.

Wilkie, W.L. (1994) Consumer Behavior, 3rd edn, New York: Wiley.

Wong, A. (2004) The role of emotional satisfaction in service encounters. Managing Service Quality 14(5): 365-376.

Wu, F., Yeniyurt, S., Kim, D. and Cavusgil, S.T. (2006) The impact of information technology on supply chain capabilities and firm performance: A resource-based view. Industrial Marketing Management 35: 493-504. 